\title{
Comparison of two treatment methods of congenital clubfoot in the orthopaedists' opinion
}

\begin{abstract}
Introduction. Clubfoot is the second most common birth defect of the lower limb. In Europe (including Poland) it concerns about 1-2 in 1000 newborns. What is characteristic for a clubfoot, is change in the foot shape and its impairment with preserving anatomical structures.

Aim. The aim of this work is to gather opinions of orthopedic physicians on the effectiveness of the two methods used to treat congenital clubfoot: the Turco method and the Ponseti method.

Material and methods. The research method used in the work was a diagnostic survey and research technique was the author's questionnaire designed to gather opinions of orthopedic surgeons on the two methods of clubfoot treatment. The questionnaires were collected in the Orthopaedic Clinics in Lublin and Rzeszów, as well as during the specialization courses for orthopaedic surgeons in Lublin.

Results. The most important advantages of the Ponseti method according to respondents are high clinical effectiveness (average 4.48) and short duration of hospitalization (average 4.31). While the most important disadvantages of the method is length of rehabilitation (average 2.85) and convalescence (average 2.36). Top assets of the Turco method in turn, according to respondents, are high clinical efficiency (average 2.92) and certainty of the patient's recovery (2.74). In turn, the downsides of the Turco method according to the respondents are high invasiveness (average 4.11) and length of convalescence (average 3.87).
\end{abstract}

Conclusion. The Ponseti method is the surveyed doctors' preferred method of congenital clubfoot treatment.

Keywords: congenital talipes equinovarus, clubfoot, lower limb defect, foot deformity, Ponseti method, Turco method.

DOI: $10.1515 /$ pjph-2017-0007

\section{INTRODUCTION}

The foot is often underrated but it is a very important organ in the human body. Proper foot morphology allows it to function properly. The actual foot construction allows for shock and energy absorption during running and walking. Its anatomically intricate main arches, longitudinal, transverse and functional have always been an inspiration for engineering solutions such as projects of bridges. The proper development of ontogenetic foot is formed after approx. 5-7 weeks of fetal life and develops in the early years of childhood and teenage years, and then affects the condition of the feet of an adult. Proper feet care, exercises and shoes variety provide comfort of walking.

The pathogenesis of idiopathic clubfoot remains unclear, previous studies indicate the multifactorial etiology. Both genetic and environmental factors may be involved in the formation of the discussed defect $[1,2]$.

\section{Methods of congenital clubfoot treatment}

Due to the long-term treatment of the defect, it requires regularity and involvement of both the doctor and the entire family of the patient [3-4]. Over the years, a number of clubfoot treat- ment methods have been developed, however, it should be pointed out that the final result of this defect treatment depends on the severity of distortion, time of the treatment beginning, the effectiveness of gypsum redression, as well as time and selection of operating methods [5-7].

\section{The method of congenital clubfoot treatment by Turco}

In 1971 the technique of Turco clubfoot treatment was described for the first time $[8,9]$. The posteromedial release and posterior medial release with subsequent modifications are preferred in many centers. The operation involves subcutaneous tenotomy of the talocalcaneonavicular (TCN) joint of a diverse range of extent. Usual interosseous talocalcaneal ligament is retained, while complex subtalar repositioning is done to the limits of preserved tissues resistance. Vincent Turco described the two indications for operation. First, is a situation in which there has been a poor performance of the previous non-surgical treatment, while the other are the bad results of previous surgical procedures $[10,11]$. Operations are performed in the arterial ischemia and a child lies on the back with a suitable rotated arrangement of the limb to expose a medial leg and foot. Skin incision runs

\footnotetext{
${ }^{1}$ Orthopaedics and Rehabilitation Supply Centre MUSI Lublin, Poland

${ }^{2}$ Department of Emergency Medicine Unit, Medical University of Lublin, Poland

${ }^{3}$ Pediatric Orthopaedic and Rehabilitation Department, Medical University, Poland

${ }^{4}$ Chair and Department of Public Health, Medical University of Lublin, Poland
} 
along the leg and bents toward the medial aspect of the foot at an angle of 90 degrees. After the posterior-medial release the foot correction should be performed naturally without the use of force. Turco describes the correctness of the foot if it secures dorsiflexion at 0 degree. As the cause of the unsatisfactory results, Turco considered incomplete compensation of a defect or lack of proper fixation of individual elements of foot after surgery. After releasing the soft tissue author of the method had several setbacks, which according to him, resulted from the instability of Kirschner wire and loss of correction, when plaster cast was used as the only stabilizer $[5,10,12]$. For many years, surgical treatment of congenital clubfoot with the Turco method was one of the most popular. A large incision of skin allowed the direct visualization of structures and the distortion correction could be performed with a high accuracy [13].

\section{The method of congenital clubfoot treatment by Ponseti}

In the 60 s of the last century Ignacio Ponseti, who conducted a number of studies on the clubfoot treatment, published the original non-surgical way to treat this defect. His method was initially underestimated by orthopaedic surgeons, however, it has gained recognition after 1990 and was introduced into medical practice in the world. Ponseti method of clubfoot treatment should be applied to patient as soon as possible. It is also important to create a comfortable environment for the child and his family during the manipulation and casting processes [14-15].

The first doctor's task is a correction of the cavus through the appropriate setting of forefoot and hindfoot. In newborns cavus is always soft and requires only setting of forefoot so to get the correct longitudinal arch of the foot. Proper alignment of the forefoot with the hindfoot will correct abnormally high arch of the foot $[14,16]$. Then the exercise is implemented, which consists of abduction of foot beneath the stabilized talar head causing all the components of clubfoot except equinus being adjusted simultaneously. The desired correction needs to be kept for several dozen of seconds, then the pressure is released and the maneuver is repeated several times [16-17]. The success in using the Ponseti method mainly requires good plastering technique. Plaster casts with described stretches are repeated at weekly intervals (Figure 1). At the time when the anterior calcaneus can be abducted under the talus, percutaneous tenotomy of the Achilles tendon can be performed with the correction of the equinus fixation in a cast lasting 3 weeks. For the first three months after the surgery it is recommended to wear up to 24 hours a day a foot abduction orthosis based on Denis-Brown splint with external rotation of 70 degrees in the affected foot, and 45 degrees in the healthy limb. After this time daily wear of the splint can be reduced, although the orthotic must be used up to 4 years of age [17-23].

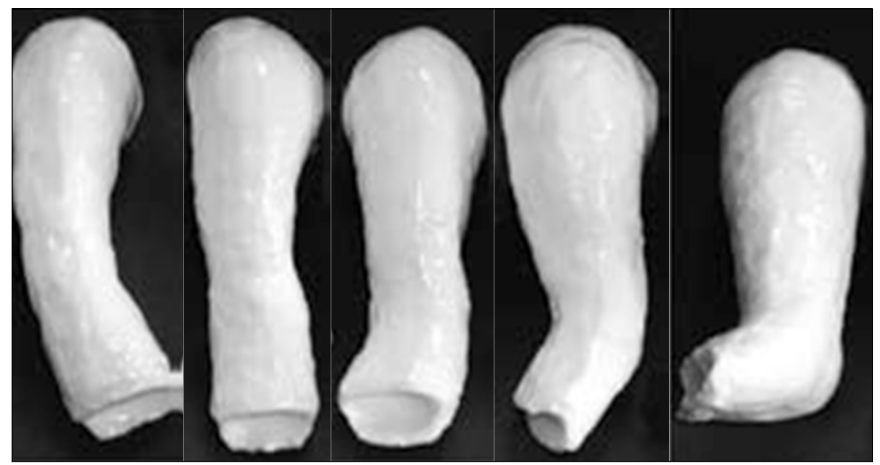

FIGURE 1. Five consecutive casts in the Ponseti method.

Source: Ponseti IV et al. Congenital clubfoot: Ponseti method treatment. The GlobalHELP Organization; 2007.

\section{AIM}

The aim of this study is to elicit the opinions of orthopedic physicians on the effectiveness of the two methods of congenital clubfoot treatment.

\section{MATERIAL AND METHOD}

The method used in the research work was diagnostic survey and research technique was the original questionnaire designed to gather orthopaedic surgeons' opinions on the two methods of clubfoot treatment: the Turco method and Ponseti method. The questionnaires were collected in the Orthopedic Clinics in Lublin and Rzeszow, as well as during the specialization courses for orthopedic surgeons in Lublin.

The results were statistically analyzed. The values of the measurable parameters are presented using mean value and standard deviation, and for non-measurable data, cardinality percentage is used.

To determine the existence of differences between the groups for qualitative characteristics $\mathrm{Chi}^{2}$, test was used. To investigate the differences between the two groups, Mann-Whitney test was applied and to compare opinions on the two analyzed methods, Student's t-test for dependent samples was used. The level of significance $\mathrm{p}<0.05$ was accepted to indicate the existence of statistically significant differences or relations. Database and statistical surveys were carried out with the computer software STATISTICA 10.0 (StatSoft, Poland).

\section{RESULTS}

Questionnaire surveys expressing opinions of 61 orthopedic surgeons were analyzed.

The study involved $85.25 \%$ men and $14.75 \%$ women. The majority of respondents $(67.21 \%)$ work in a big city, while $31.15 \%$ of respondents indicated that they work in a small town. Clinical hospitals were represented by $37.70 \%$ of the respondents, county hospitals and provincial hospitals were each represented by $24.59 \%$ of the respondents. Among the respondents, $52.46 \%$ were doctors with six years of experience and $47.54 \%$ were doctors who have been working 7 years and more. The study involved $60.66 \%$ of physicians during specialization and $39.34 \%$ specialists (Table 1 ).

TABLE 1. Socio-demographic data.

\begin{tabular}{lccc}
\hline \hline \multirow{2}{*}{ Analyzed variable } & N & \% \\
\hline \multirow{2}{*}{ Work location } & Women & 9 & 14.75 \\
& Men & 52 & 85.25 \\
\hline \multirow{4}{*}{ Workplace } & City & 19 & 31.15 \\
& Rural area & 41 & 67.21 \\
& Clinical hospital & 1 & 1.64 \\
\hline \multirow{2}{*}{ Work experience } & Town hospital & 8 & 37.70 \\
& Provincial hospital & 15 & 24.59 \\
\hline \multirow{2}{*}{ Specialization } & County hospital & 15 & 24.59 \\
\hline & Up to 6 years & 32 & 52.46 \\
& 7 years or more & 29 & 47.54 \\
\hline & Specialist & 24 & 39.34 \\
& During specialization & 37 & 60.66 \\
\hline
\end{tabular}


TABLE 2. Number of clubfoot cases per year.

\begin{tabular}{|c|c|c|c|c|c|c|c|}
\hline & Variable & & Up to 5 & $\begin{array}{c}\text { from } 5 \\
\text { to } 10\end{array}$ & $\begin{array}{c}\text { from } 10 \\
\text { to } 20\end{array}$ & $\begin{array}{c}\text { More } \\
\text { than } 20\end{array}$ & $\begin{array}{l}\mathbf{Z} \\
\mathbf{p}\end{array}$ \\
\hline \multirow{4}{*}{ 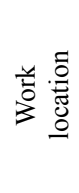 } & \multirow{2}{*}{ Small town } & $\mathrm{N}$ & 11 & 2 & 6 & 0 & \multirow{4}{*}{$\begin{array}{l}\mathrm{Z}=1.176 \\
\mathrm{p}=0.240\end{array}$} \\
\hline & & $\%$ & $57.89 \%$ & $10.53 \%$ & $31.58 \%$ & $0.00 \%$ & \\
\hline & \multirow{2}{*}{ Large city } & $\mathrm{N}$ & 18 & 6 & 10 & 7 & \\
\hline & & $\%$ & $43.90 \%$ & $14.63 \%$ & $24.39 \%$ & $17.07 \%$ & \\
\hline \multirow{4}{*}{ 范 } & & $\mathrm{N}$ & 20 & 3 & 5 & 4 & \multirow{4}{*}{$\begin{aligned} Z & =-1.935 \\
p & =0.053\end{aligned}$} \\
\hline & ears & $\%$ & $62.50 \%$ & $9.38 \%$ & $15.63 \%$ & $12.50 \%$ & \\
\hline & \multirow{2}{*}{$\begin{array}{l}7 \text { years or } \\
\text { more }\end{array}$} & $\mathrm{N}$ & 9 & 6 & 11 & 3 & \\
\hline & & $\%$ & $31.03 \%$ & $20.69 \%$ & $37.93 \%$ & $10.34 \%$ & \\
\hline \multirow{4}{*}{ 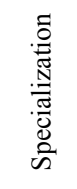 } & \multirow{2}{*}{ Specialist } & $\mathrm{N}$ & 5 & 6 & 10 & 3 & \multirow{4}{*}{$\begin{array}{l}Z=2.746 \\
p=0.006\end{array}$} \\
\hline & & $\%$ & $20.83 \%$ & $25.00 \%$ & $41.67 \%$ & $12.50 \%$ & \\
\hline & During & $\mathrm{N}$ & 24 & 3 & 6 & 4 & \\
\hline & specialization & $\%$ & $64.86 \%$ & $8.11 \%$ & $16.22 \%$ & $10.81 \%$ & \\
\hline \multirow{2}{*}{ Total } & & $\mathrm{N}$ & 29 & 9 & 16 & 7 & \\
\hline & & $\%$ & 47.54 & 14.75 & 26.23 & 11.48 & \\
\hline
\end{tabular}

* in case of work location analysis does not include one person working in the countryside

The analysis of the doctors' opinions on the number of orthopedic treatment of congenital clubfoot showed that almost half (47.54\%) of all physicians treat up to 5 cases of congenital clubfoot per year and every 4 th $(26.23 \%)$ cures from 10 to 20 cases per year. In small towns there were no more than 20 cases of treatment per year, however, in large cities $17.07 \%$ of doctors treat more than 20 cases of clubfoot per year. Specialists treat significantly more cases of clubfoot than doctors during specialization $(Z=2.746, \mathrm{p}=0.006)$. The results of this analysis are presented in Table 2.

The vast majority of respondents $(90.16 \%)$ prefer Ponseti technique as a method of congenital clubfoot treatment, while every tenth respondent $(9.84 \%)$ chose Turco method. There were no statistically significant differences in the choice of the preferred methods between doctors from small and large cities $\left(\mathrm{Chi}^{2}=0.308\right.$, $\mathrm{p}=0.579$ ). There is also no statistically significant difference in the selection of the preferred method among physicians with 6 years experience and those with 7 years and more $\left(\mathrm{Chi}^{2}=2.012\right.$, $\mathrm{p}=0.156$ ). The same situation is in case of specialists and doctors during the course of specialization $\left(\mathrm{Chi}^{2}=1.005, \mathrm{p}=0.316\right)$.

Table 3 presents the opinions of doctors on the more favorable method based on the long-term results of congenital clubfoot treatment.

TABLE 3. Evaluation of more effective long-term results using the two methods.

\begin{tabular}{|c|c|c|c|c|c|c|}
\hline \multicolumn{3}{|c|}{ Analyzed variable } & $\begin{array}{c}\text { After } \\
\text { treatment } \\
\text { with Ponseti } \\
\text { method } \\
\end{array}$ & $\begin{array}{c}\text { After } \\
\text { treatment } \\
\text { with Turco } \\
\text { method } \\
\end{array}$ & $\begin{array}{c}\text { No } \\
\text { difference }\end{array}$ & $\begin{array}{c}\text { I don't } \\
\text { have any } \\
\text { opinion }\end{array}$ \\
\hline \multirow{4}{*}{ 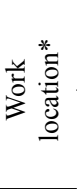 } & \multirow{2}{*}{$\begin{array}{l}\text { Small } \\
\text { town }\end{array}$} & $\mathrm{N}$ & 11 & 0 & 4 & 4 \\
\hline & & $\%$ & $57.89 \%$ & 0.00 & $21.05 \%$ & $21.05 \%$ \\
\hline & \multirow{2}{*}{ Large city } & $\mathrm{N}$ & 34 & 0 & 3 & 4 \\
\hline & & $\%$ & $82.93 \%$ & 0.00 & $7.32 \%$ & $9.76 \%$ \\
\hline \multirow{4}{*}{ y } & \multirow{2}{*}{$\begin{array}{l}\text { Up to } \\
6 \text { years }\end{array}$} & $\mathrm{N}$ & 26 & 0 & 2 & 4 \\
\hline & & $\%$ & $81.25 \%$ & 0.00 & $6.25 \%$ & $12.50 \%$ \\
\hline & \multirow{2}{*}{$\begin{array}{l}7 \text { years } \\
\text { or more }\end{array}$} & $\mathrm{N}$ & 20 & 0 & 5 & 4 \\
\hline & & $\%$ & $68.97 \%$ & 0.00 & $17.24 \%$ & $13.79 \%$ \\
\hline \multirow{4}{*}{ 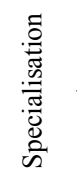 } & \multirow{2}{*}{ Specialist } & $\mathrm{N}$ & 18 & 0 & 5 & 1 \\
\hline & & $\%$ & $75.00 \%$ & 0.00 & $20.83 \%$ & $4.17 \%$ \\
\hline & \multirow{2}{*}{$\begin{array}{c}\text { During } \\
\text { specialization }\end{array}$} & $\mathrm{N}$ & 28 & 0 & 2 & 7 \\
\hline & & $\%$ & $75.68 \%$ & 0.00 & $5.41 \%$ & $18.92 \%$ \\
\hline
\end{tabular}

The vast majority of respondents $(75.41 \%)$ indicated the Ponseti method as better. One in ten (11.48\%) respondents indicated no vast difference between the given methods, while $13.11 \%$ of physicians had no opinion. None of the respondents indicated Turco method as better. Regardless of work location, whether working in a small town $(57.89 \%)$ or in a big city $(82.93 \%)$, the majority of respondents believed that the Ponseti method is more effective because of the long-term results of congenital clubfoot treatment. The majority of doctors with work experience up to six years $(81.25 \%)$ chose the Ponseti method, while $12.5 \%$ of doctors had no opinion. Among doctors with work experience of 7 years or more, the majority (68.97\%) admitted that the Ponseti method is a better one because of long-term results, but $17.24 \%$ did not see the vast difference between the two methods.

In the next part of the survey orthopaedists were asked to give reasons for choosing their preferred method of congenital clubfoot treatment. Table 4 shows the positive features of the studied congenital clubfoot treatment methods in the orthopedic surgeons' view.

TABLE 4. Positive features of the studied congenital clubfoot treatment methods in the evaluation of orthopedic surgeons.

\begin{tabular}{|c|c|c|c|c|c|c|}
\hline \multirow{2}{*}{ Advantages } & \multicolumn{4}{|c|}{ Turco method Ponseti method } & \multicolumn{2}{|c|}{ Differences } \\
\hline & $\mathbf{M}$ & SD & $\mathbf{M}$ & SD & $\mathbf{t}$ & $\mathbf{p}$ \\
\hline $\begin{array}{l}\text { Greater certainty of } \\
\text { patient's recovery }\end{array}$ & 2.74 & 0.98 & 4.05 & 0.99 & -6.542 & $<0.001$ \\
\hline Shorter recovery period & 2.44 & 1.04 & 3.82 & 1.12 & -6.539 & $<0.001$ \\
\hline $\begin{array}{l}\text { High clinical effectiveness } \\
\text { of the given method }\end{array}$ & 2.92 & 1.11 & 4.48 & 0.65 & -9.373 & $<0.001$ \\
\hline $\begin{array}{l}\text { Lower cost of treatment } \\
\text { with Turco method } \\
\text { than Ponseti method }\end{array}$ & 2.49 & 1.03 & 3.87 & 1.09 & -5.772 & $<0.001$ \\
\hline Short hospitalisation time & 2.03 & 0.95 & 4.31 & 0.90 & -13.249 & $<0.001$ \\
\hline
\end{tabular}

The importance of each feature was marked with numbers from 1 to 5 , where 1 is the least important feature for respondents, while 5 is the most important one. It turned out that among the positive features of the Ponseti method rated by the doctors as the highest are: "high clinical efficacy of the method" (average 4.48) and "a short period of hospitalization after the method" (average 4.31), while among the lowest - rated was: "fast recovery time" (average of 3.82). Among the positive features of Turco method, highly - rated were: "high clinical effectiveness of the method" (average 2.92) and "greater certainty of patient recovery" (average 2.74 ), while the lowest - rated evaluated by doctors were short hospitalization time after the method" (2.03 standard). There was a strong statistically significant difference in opinions on the positive features of the two methods. Subsequently, respondents expressed their opinion on the negative traits of the Ponseti and Turco treatment methods, the results are shown in Table 5.

TABLE 5. Negative features of the studied congenital clubfoot treatment methods in the evaluation of orthopedic surgeons.

\begin{tabular}{|c|c|c|c|c|c|c|}
\hline \multirow{2}{*}{ Disadvantages } & \multicolumn{4}{|c|}{ Turco method Ponseti method } & \multicolumn{2}{|c|}{ Differences } \\
\hline & $\mathbf{M}$ & SD & M & SD & $\mathbf{t}$ & $\mathbf{p}$ \\
\hline Long time of recovery & 3.87 & 0.81 & 2.36 & 1.18 & 7.677 & $<0.001$ \\
\hline $\begin{array}{l}\text { Great invasiveness of } \\
\text { the method }\end{array}$ & 4.11 & 1.00 & 1.80 & 0.96 & 10.064 & $<0.001$ \\
\hline $\begin{array}{l}\text { Little clinical effective- } \\
\text { ness of the method }\end{array}$ & 3.26 & 1.00 & 1.77 & 0.86 & 8.797 & $<0.001$ \\
\hline $\begin{array}{l}\text { Long convalescence } \\
\text { after the method }\end{array}$ & 3.51 & 1.03 & 2.85 & 1.25 & 2.865 & 0.006 \\
\hline $\begin{array}{l}\text { Long hospitalisation } \\
\text { time after the method }\end{array}$ & 3.46 & 0.94 & 1.82 & 0.97 & 9.540 & $<0.001$ \\
\hline High cost of treatment & 3.46 & 0.77 & 2.11 & 1.05 & 7.431 & $<0.001$ \\
\hline
\end{tabular}


Just as in the previous question the importance of each feature was marked with numbers from 1 to 5 , where 1 is the least important feature for respondents, while 5 is the most important one. Among the negative features of the Turco method respondents rated the following as the highest: "high invasiveness of the method" (average 4.11) and "a long time of recovery" (average 3.87). Among the negative opinions about the Ponseti method high rates were given to: "long period of rehabilitation after the method" (average 2.85) and "a long time to return to fitness" (average 2.36). There was a statistically significant difference in the opinions on the negative aspects of the Ponseti and Turco methods. Another issue examined in the study was related to the problems associated with the introduction of Ponseti method for the treatment of congenital clubfoot in the evaluation of orthopedic surgeons. The importance of this issue was also marked with numbers from 1 to 5 where 1 meant the least important feature for respondents, while 5 indicated the most important one. As the most important issue "lack of sufficient training of staff in the method" was chosen (average 3.43), while the least important issue was the "fear of change" (average 2.63).

\section{DISCUSSION}

Clubfoot is the second most common birth defect of the lower limb[7,24-25]. Among respondents 47.54\% indicated that they treat up to 5 cases of congenital clubfoot per year, $14.75 \%$ of respondents treat from 5 to 10 cases of the discussed defects while nearly a quarter $(26.23 \%)$ treat from 10 to 20 clubfoot cases per year. No doctor working in a small town cures more than 20 cases of clubfoot per year, while $17.07 \%$ of physicians from a large city indicated that they treat more than 20 cases per year. Specialists treat clubfoot significantly more often than doctors during specialization, the difference is statistically significant $(\mathrm{p}=0.006)$. In a study conducted in 2012 by the Ziontsa and others, 323 members of POSNA were examined and it was shown that in a given year doctors treated the average of 23.5 clubfoot cases [26].

Ponseti method is preferred by the vast majority of respondents $(90.16 \%)$, while the method by Turco was chosen by $9.84 \%$ of the respondents. There were no statistically significant differences in the selection of the preferred methods between doctors from small and large cities $\left(\mathrm{Chi}^{2}=0.308\right.$, $\mathrm{p}=0.579$ ), with experience up to 6 years and 7 years or more $\left(\mathrm{Chi}^{2}=2.012, \mathrm{p}=0.156\right)$ and due to their specialization $\left(\mathrm{Chi}^{2}=1.005, \mathrm{p}=0.316\right)$. Zionts et al. in their study showed that almost all the respondents $(96.7 \%)$ indicated Ponseti method as the best method of treatment clubfoot [26]. In the study of Jayawardene et al. from 2013, 131 surveys of specialists treating clubfoot were analyzed [27]. The vast majority of respondents $(97 \%)$ assessed Ponseti method as the preferred treatment of clubfoot. The survey of Radler et al. from 2013 shows that in $95 \%$ of clubfoot cases further surgical treatment can be avoided using Ponseti method [28].

Respondents were asked to indicate the method after which the long-term results are better. $75.41 \%$ of respondents indicated Ponseti method, while $11.48 \%$ did not see the vast difference between the two methods. No one pointed out Turco as the surgical method after which the long-term outcomes are better. Morcuendei et al. evaluated in their study the long-term results of clubfoot treatment. Authors have examined people being treated for clubfoot in two separate hospitals and treated by two different methods in 1983-1987. One hospital used only Ponseti method, while the other hospital used mainly comprehensive release of clubfoot. The study included 42 adults 24 treated surgically and 18 treated with the Ponseti method. Although people from both treatment groups experienced pain, weakness and reduced ROM, they all functioned well in their adulthood. The group treated by the Ponseti method scored better than the group treated only with surgery. This is due to the benefits that come with treatment using the Ponseti method, that is increased ROM observed in physical examination and while walking, greater endurance rates and fewer complications associated with joints straining. These studies have demonstrated the superiority of the method according to Ponseti over the comprehensive release method [29].

Opinions of orthopedic surgeons on the positive features of the two methods of clubfoot treatment were compared. Among the top rated positive features of the method according to Turco, respondents indicated "high clinical efficacy of the method" (average 2.92) and "certainty of patient's recovery" (average 2.74). In the Ponseti method physicians also rated highly "high clinical efficacy of the method" (average 4.48) and "a short period of hospitalization after the method." There was a statistically significant difference between opinions on all positive features of the Ponseti and the Turco methods $(p<0.001)$.

The opinions of orthopedic surgeons on the negative characteristics of the two methods of clubfoot treatment were compared. Among the most significant negative features of the Turco method according to orthopedists were "high invasiveness of the method" (average 4.11) and in the Ponseti method "a long period of rehabilitation after the method" (average 2.85). The least significant negative aspect of both Turco (average 3.26) and Ponseti method (average 1.77) is "little clinical effectiveness of the method." Feature "high cost of treatment of a given method" has been assessed as more negative in the Turco method than in Ponseti method. In the study of Hussain, H. and others., cost of the two clubfoot treatment methods were compared. The survey shows that the average cost of surgical method is more than twice higher than the average cost of treatment with Ponseti method [30]. There were statistically significant differences in all negative traits of the Ponseti and the Turco methods.

The introduction of new treatment techniques may be associated with various problems. Fear of change, the resistance of staff or lack of the sufficient knowledge or training may be reasons for the negative attitude towards the new method. Respondents were asked to identify the problems associated with the introduction of new clubfoot treatment techniques - the Ponseti method. Doctors pointed out "lack of sufficient training of staff in the method" as the biggest problem (average 3.43 ), while the least serious problem was the "fear of change" (average 2.63). The analysis of the discussed problems according to the work location has been made. It turned out that both, doctors working in a big cities and doctors working in a small towns, assessed the feature "lack of adequate training of personnel in the field" as the biggest problem. Answers for this feature are statistically significantly different $(p=0.012)$. All the problems associated with the introduction of the new method were rated as more important for doctors working in a small town. The analysis of the problems according to the possessed specialization was also conducted. It turned out that all problems related to the introduction of a new method of clubfoot treatment, were rated as more important for physicians during specialization than for specialists. 
Research presented above is one of the first studies concerning doctors orthopedists' opinions on the different methods of treating clubfoot.

\section{CONCLUSIONS}

1. The Ponseti method is the preferred method of congenital clubfoot treatment among the surveyed doctors.

2. Respondents agreed that long-term results of congenital clubfoot treatment are better after the Ponseti method treatment than after the Turco method.

3. Top positive features of the Turco method according to respondents' opinions are high clinical effectiveness of the method (average 2.92) and certainty of patient's recovery (2.74).

4. Top positive features of the Ponseti method according to respondents is high clinical effectiveness of the method (average 4.48), and short time of hospitalization after the treatment (average 4.31).

5. The most important negative feature of the Turco method in the opinion of the respondents is high invasiveness of the method (average 4.11) and long recovery time (average 3.87).

6 . The most important negative feature of the Ponseti method according to the respondents is a long period of rehabilitation after the method (average 2.85) and a long convalescence time (average 2.36).

\section{REFERENCES}

1. Lykissas MG, Crawford AH, Eismann EA, Tamai J. Ponseti method compared with soft-tissue release for the management of clubfoot: A metaanalysis study. World J Orthop. 2013;18,4(3):144-53.

2. Handelsman JE, Badalamente MA. Neuromuscular studies in clubfoot. J Pediatr Orthop. 1981;1:23-32.

3. Ostrowski J, Karski T, Okoński M. Zmiany kształtu i ustawienia kości skokowej u osób operowanych w dzieciństwie z powodu wrodzonych stop końsko-szpotawych. Chir Narz Ruchu Ortop Pol. 1996;61(Suppl. 3A):261-5.

4. Karski T. Wośko I. Experience In the conservative treatment of congenital clubfoot In newborns and infants. J. Pediatr Orthop. 1989;9:134-6.

5. Karski T, Ostrowski J, Tarczyńska M, et al. Wyniki leczenia operacyjnego wrodzonych stop końsko-szpotawych techniką Turco i Goldnera z modyfikacją własną. Kwart Ortop. 2001;2:120-4.

6. Fujak A, Forst R, Forst J. Outcome after Achilles ten don lengthening with a posteriori capsulosis according to imhauser In idiopathic congenital clubfoot. OTR. 2008;4(6):367-76.

7. Cummings RJ, Davidson RS, Armstrong PF, Lehman WB. Congenital clubfoot. J Bone Joint Surg. 2002;84:290-308.

8. Papavasiliou V, Papavasiliou A. A novel surgical option for the operative treatment of clubfoot. Acta Orthop Belg. 2004;70:155-61.

9. Turco VJ. Surgical correction of the resistant clubfoot. One stage posteromedial release with internal fixation : a preliminary report. J Bone Joint Surg. 1971;53-A:477-97.

10. Karski T, Tarczyńska M, Ostrowski J, et al. Leczenie operacyjne wrodzonej stopy końsko-szpotawej techniką uwolnienia tylno-przyśrodkowego - odniesienie do metody Turco na podstawie własnych obserwacji. Chir Narz Ruchu Ortop Pol. 2001;66(3):275-84.

11. Turco VJ. Surgical correction of the resistant club foot. J Bone Joint Surg. 1971;53A(3):477-97.

12. Hussain S, Khan MS, Ali MA. Modified Turco's postero-medial release for congenital talipesequino-varus. J Ayub Med Coll Abbottabad. 2008;20(3):78-80

13. Siddiqui M, Pirwani M, Bhura S. Window procedure versus Turco procedure for the treatment of talipes equinovarus. Pakistan J Surg. 2007;23(3):212-6.

14. Ponseti IV. Wrodzona stopa końsko-szpotawa: leczenie metodą Ponsetiego. Global-HELP Organization; 2007.

15. Bhargava SK, Tandon A, Prakash M, et al. Radiography and sonography of clubfoot: A comparative study. Indian J Orthop. 2012;46(2):229-35.
16. Kowalczyk B., Lejman T. Podstawy metody Ponseti w leczeniu wrodzonych stóp końsko-szpotawych. OTR. 2007;9(4):436-40.

17. Niedzielski K, Małecki K, Kosińska M, Lipczyk Z. Wczesne wyniki leczenia stopy końsko-szpotawej wrodzonej metodą Ponsetiego. Chir Narz Ruchu Ortop Pol. 2011;76(5):247-51.

18. Morcuende JA, Dolan LA, Dietz FR, Ponseti IV. Radical reduction In the rate of extensive corrective burgery for clubfoot Rusing the Ponsetimetod. Pediatrics. 2004;113(2):376-80.

19. Zionts LE, Dietz FR. Bracing following correction of idiopathic clubfoot using the Ponseti method. J Am Acad Orthop Surg. 2010;18:486-93.

20. Ponseti IV. Treatment of congenital clubfoot. J Bone Joint Surg Am.1991;448-54.

21. Laaveg SJ, Ponseti IV. Long-term results of treatment of congenital club foot. J Bone Joint Surgery Am. 1980;62:23-31.

22. Niki H, Nakajima H, Hirano T, et al. Ultrasonographic observation of the healing process in the gap after a Ponseti-type Achilles tenotomy for idiopathic congenital clubfoot at two-year follow-up. J Orthop Sci. 2013;18(1):70-5.

23. Hemo Y, Segev E, Yavor A, et al. The influence of brace type on the success rate of the Ponseti treatment protocol for idiopathic clubfoot. J Child Orthop. 2011;5(2):115-9.

24. Matuszewski Ł, Okoński M, Gil L, Okoński P. Korzyści w leczeniu stopy końsko szpotawej u dzieci przy pomocy metody Ponsetiego - lepsza efektywność przy mniejszej inwazyjności, Zdr Publ. 2013;123(1):53-6.

25. Okoński P, Misztal-Okońska P, Okoński M, et al. Frequency of hospitalization in patients diagnosed with congenital talipes equinovarus (CTEV). Pol J Public Health. 2015;125(4):219-22.

26. Zionts LE, Sangiorgio S, Ebramzadeh E, Morcuende J. The current management of idiopathic clubfoot revisited: results of a survey of the POSNA membership. J Pediatr Orthop. 2012;32(5):515-20.

27. Jayawardena A, Zionts LE, Morcuende JA. Management of idiopathic clubfoot after formal training in the ponseti method: A multi-year, international survey. Iowa Orthop J 2013;33:136-41.

28. Radler C, Mindler GT, Riedl K, et al. Midterm results of the Ponseti method in the treatment of congenital clubfoot. Int Orthop. 2013;37(9):182731.

29. Smith PA, Kuo KN, Graf AN, et al. Long-term results of comprehensive clubfoot release versus the Ponseti method: which is better? Clin Orthop Relat Res. 2014;472(4):1281-90.

30. Hussain H, Burfat AM, Samad L, et al. Cost-Effectiveness of the Ponseti Method for Treatment of Clubfoot in Pakistan. World J Surg. 2014;38(9):2217-22.

\section{Corresponding author}

Patrycja Misztal-Okońska

Department of Expert Medical Assistance with Emergency Medicine Unit,

Medical University of Lublin

4/6 Staszica St., 20-081 Lublin

E-mail: patrycja.okonska@umlub.pl 